\title{
Article \\ Operational Costs of Mid-Performance Forwarders in Czech Forest Bioeconomy
}

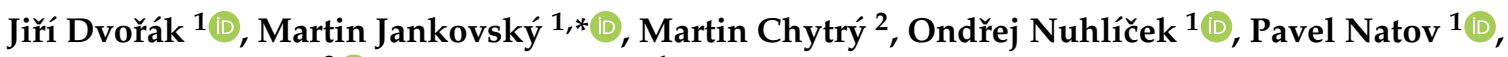 \\ Mariusz Kormanek $^{3}$ (i) and Radim Löwe ${ }^{1}$
}

1 Department of Forestry Technologies and Construction, Faculty of Forestry and Wood Sciences, Czech University of Life Sciences Prague, Kamýcká 129, 16500 Prague, Czech Republic; dvorakj@fld.czu.cz (J.D.); nuhlicek@fld.czu.cz (O.N.); natov@fld.czu.cz (P.N.); lowe@fld.czu.cz (R.L.)

2 Vojenské Lesy a Statky, GOE, Pod Juliskou 1621/5, 16500 Prague, Czech Republic; martin.chytry@vls.cz

3 Department of Forest Utilization, Engineering and Forest Technology, Faculty of Forestry, University of Agriculture in Cracow, Al. 29 Listopada 46, 31-425 Cracow, Poland; rlkorma@cyf-kr.edu.pl

* Correspondence: jankovskym@fld.czu.cz

Citation: Dvořák, J.; Jankovský, M.; Chytrý, M.; Nuhlíček, O.; Natov, P.; Kormanek, M.; Löwe, R. Operational Costs of Mid-Performance

Forwarders in Czech Forest

Bioeconomy. Forests 2021, 12, 435 .

https://doi.org/10.3390/f12040435

Academic Editor: Gianni Picchi

Received: 26 February 2021

Accepted: 1 April 2021

Published: 4 April 2021

Publisher's Note: MDPI stays neutral with regard to jurisdictional claims in published maps and institutional affiliations.

Copyright: (C) 2021 by the authors. Licensee MDPI, Basel, Switzerland. This article is an open access article distributed under the terms and conditions of the Creative Commons Attribution (CC BY) license (https:// creativecommons.org/licenses/by/ $4.0 /)$.

\begin{abstract}
Cut-to-length (CTL) operations are expanding in Central European bio-economies. However, they are costly, so efficiency must be maximized. The objective of this study was to analyze direct operational costs of three forwarders from the year 2006 until 2019. Annual amortization, services, materials, and personnel costs were analyzed and compared through ANOVA, trends were analyzed through linear regression. Forwarders LVS 5, John Deere 1010, and John Deere 1110E were deployed in coniferous forest stands with a mean stem volume between 0.10 and $0.84 \mathrm{~m}^{3} / \mathrm{stem}$, forwarding distance between 261 and $560 \mathrm{~m}$. The machines forwarded between 4045 and 34,604 $\mathrm{m}^{3}$ of timber per year, over operational times between 490 and $3896 \mathrm{MH}$ (machine hours)/year, reaching machine utilization between $58 \%$ and $89 \%$, machine productivity between 3.5 and $12.3 \mathrm{~m}^{3} / \mathrm{MH}$, and costs between 20.95 and $84.39 € / \mathrm{MH}$. The most substantial were personnel costs (35 to $66 \%$ of the total costs), followed by materials (14.9-27.1\%), amortization (12.5-15.7\%), and services (3.3-22.1\%). Differences between total operational costs per $\mathrm{m}^{3}$ of machines with different engine powers were not observed.
\end{abstract}

Keywords: CTL harvesting; amortization; personnel costs; material costs; repairs and maintenance; productivity

\section{Introduction}

The first forwarders (e.g., Volvo BM 971) were used in Czechia during the year of 1977. They tackled the pollution disturbances in Krušné hory [1]. However, the expansion of forwarders to the position of one of the main machines used in timber extraction came at the end of the millennium. Several factors contributed to this, from the decrease of the availability of qualified personnel for forest operations, increasing personnel costs, to the increasing share of incidental felling. These, and other, reasons lead to the increasing use of the cut-to-length (CTL) harvesting method in Czechia, connected to harvester technology, from an $11 \%$ share on total annual harvests in 2005 to $44 \%$ in the year 2019 (Figure 1) [2]. The share of CTL harvesting in 2019 was partially caused by the need to rapidly process timber from the bark beetle calamity. However, forwarders are not used exclusively in tandem with harvesters, they frequently forward timber logged by chain saws, as documented by the fact that there are 453 more forwarders than harvesters in Czechia [2].

Trends similar to those visible in Czechia can be seen in other Central and Eastern European countries, like Estonia (95\% share in final cut; 80\% in thinning), Latvia (70\% share overall) [3]. Besides the economic situation of the country's forestry sector, expansion of the harvester technology depends on conditions as terrain configuration, tree species composition, forest management, etc. Czech conditions enable an increase in usage of 
harvester technology. In particular regions, up to $79 \%$ of forest area are favorable for harvester deployment [4]. Overall, Dvořák and Natov [5] state that forwarders can be used on approximately $72 \%$ (1.88 million ha; 530 million $\mathrm{m}^{3}$ of timber stocks) of all Czech forests. These forests are located on sites with high load bearing capacities, low-enough slopes, and suitable tree species compositions [1]. Conversely, forestry sectors in countries like Bulgaria or Ukraine, where forests are located on steep slopes, deciduous trees are abundant, and where the forestry sector is undercapitalized are yet to extensively adopt harvester technology [3].

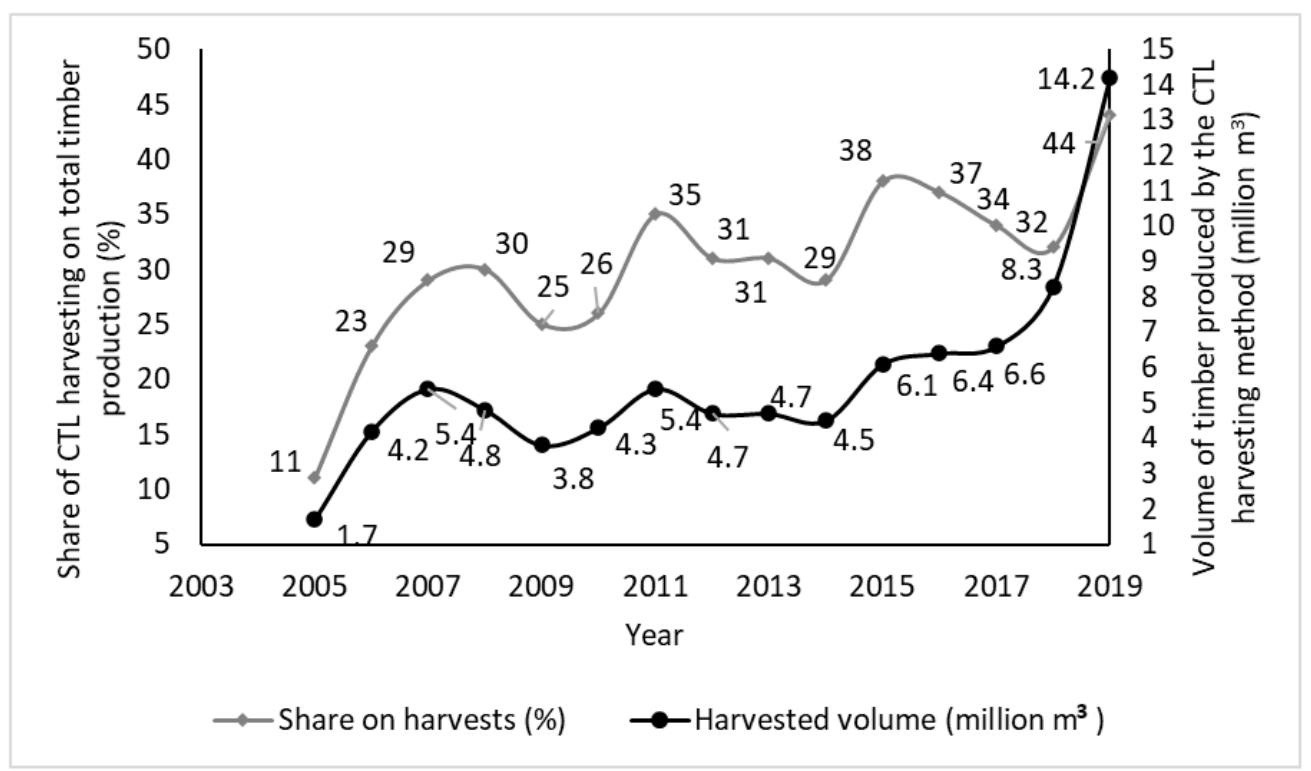

Figure 1. Share and volume of timber produced by the cut-to-length (CTL) harvesting method in Czechia during the years 2005-2019 [2].

Bio-based products and services are likely to become increasingly important and demanded, as they mature in their lifecycles, caused by the role of bioeconomy in climate change mitigation and adaptation. Therefore, any forest value chain needs to maximize the efficiency of all its lings, including timber forwarding as an essential technological operation of extracting timber from the forest floor to the roadside. Any forest harvesting technology must be deployed so that it is productive and profitable. Therefore, prior to any economic analysis, analyzing the operation of a machine is suggested, from which, economic costs are inferred. Many authors focused on predicting or explaining the productivity of forest machinery [5-19]. The accuracy of the analyses is increasing, as they no longer rely on manual measurements and limited data, but rather on the abundant data from the on-board forest machine systems $[15,20]$.

Productivity of forwarders depends on factors such as mean volume of forwarded stem (mean stem volume; MSV), forwarding distance, terrain conditions, harvesting intensity and type, machine performance class, its bunk capacity, and others $[1,5,7-11,17,19,21-23]$. Forwarders with a bunk capacity up to $3 \mathrm{~m}^{3}$ are able to forward from 2 to $4.1 \mathrm{~m}^{3} / \mathrm{MH}$, whereas those with approximately $12 \mathrm{~m}^{3}$ bunks typically forward between 7.1 and $20 \mathrm{~m}^{3} / \mathrm{MH}$ [1]. Regarding the MSV, authors report forwarder productivity at 18 to $27 \mathrm{~m}^{3}$ /Productive machine hour with 15 min delays $\left(\mathrm{PMH}_{15}\right)$ in final cuts (high MSV) [14,24], whereas studies $[24,25]$ report a range between 13 and $28 \mathrm{~m}^{3} / \mathrm{PMH}_{15}$ in thinning (low MSV). In all of these studies, increasing forwarding distance translates to decreasing productivity. Furthermore, producing shorter logs is more time consuming, i.e., costlier per $\mathrm{m}^{3}$ than producing longer logs $[14,18,26]$. Personnel, too, is an important factor in forwarder performance, affecting up to $40 \%$ of their productivity $[15,27]$. In short, there are numerous factors that affect machine productivity. Therefore, to simplify predictions, productivity is often 
predicted based on the MSV, and forwarding distance, structured according to machine performance class $[28,29]$.

Increasing productivity typically causes a decrease in operational costs per cubic meter of timber [30]. On the other hand, lower performance machines need smaller investments and can be a good solution for thinning $[8,9,31,32]$. Nevertheless, forwarders must be utilized properly to ensure the return of invested capital. Their mean utilization is $1581 \mathrm{MH} /$ year [33], thus reaching a utilization rate up to $84 \%$ [24].

The aim of this study was to analyze the operational costs of forwarders operated by companies that deployed the machines they owned in forests they managed. Including both smaller and larger machines of the mid-performance class, that were either completely amortized or still undergoing the process enabled to compare the differences between the machines and the effects of this cost group on machine operation.

\section{Material and Methods}

\subsection{Machines Analysed}

This study focused on forwarders owned by Vojenské lesy a statky ČR, s.p., Hořovice division (Military Forests and Estates of the Czech Republic; "VLS"; GPS coordinates of the headquarters: 49.78186732228961, 13.988176060239534) and Lesy České republiky, s.p., Forest district Kladská (Forests of the Czech Republic; "LCR"; GPS coordinates of the headquarters: 50.00708154027139, 12.631463299354868), both state owned enterprises. Both the headquarters of VLS and LCR were located roughly at the centre of the respective forest areas the companies managed. The forwarders were used exclusively in forests managed by each company. Forests managed by VLS spanned on 28,000 ha, LCR managed 15,000 ha of forests where their machine operated. Tree species composition was favorable for using the harvester technology in both Hořovice division ( $83 \%$ coniferous species) and Forest district Kladská (90.5\% coniferous species). The machines worked on sites suitable for forwarders according to [6], their transfers were minimized, and were rarely deployed to work in other divisions or districts, only to help processing incidental fellings. Forwarders were used primarily in stands up to 80 year of the forest stand age [34].

All forwarders were purchased as new. John Deere 1010 (JDA) was operated between the years 2004 and 2015, Novotny LVS (LVS), was operated between 2008 and 2016, and John Deere 1110E (JDB) was purchased in 2017 and is still in operation (Table 1). Technical parameters of the machines can be seen in Table 2 .

Table 1. Operational and investment data of the particular forwarders.

\begin{tabular}{ccccc}
\hline Brand & $\begin{array}{c}\text { Date of Purchase } \\
\text { (Month/Year) }\end{array}$ & $\begin{array}{c}\text { Purchase Price } \\
\text { (EUR) }\end{array}$ & $\begin{array}{c}\text { Date of Sale } \\
\text { (Month/Year) }\end{array}$ & $\begin{array}{c}\text { Sale Price } \\
\text { (EUR) }\end{array}$ \\
\hline John Deere 1010 & $4 / 04$ & 177,185 & $3 / 15$ & 0 \\
Novotny LVS 5 & $4 / 08$ & 84,122 & $4 / 16$ & 14,828 \\
John Deere 1110E & $2 / 17$ & 331,481 & & \\
\hline
\end{tabular}

Table 2. Forwarder technical information.

\begin{tabular}{|c|c|c|c|c|}
\hline \multicolumn{2}{|c|}{ Parameter } & \multirow{3}{*}{$\begin{array}{c}\text { John Deere } \mathbf{1 0 1 0} \\
11.4 \\
2.68\end{array}$} & \multirow{3}{*}{$\begin{array}{c}\text { Novotný LVS } 5 \\
5.5 \\
2.10\end{array}$} & \multirow{3}{*}{$\begin{array}{c}\text { John Deere 1110E } \\
14.7 \\
2.72\end{array}$} \\
\hline & Weight (kg) & & & \\
\hline Base machine & Width (m) & & & \\
\hline \multirow{2}{*}{ Engine } & Type & Perkins 1004-4T & FPT-F34 & John Deere 4045 \\
\hline & Power (kw) & 82 & 55 & 115.5 \\
\hline \multirow{3}{*}{ Bunk } & Length (m) & 4.63 & 3.7 & 4.5 \\
\hline & Width (m) & 2.48 & 2.4 & 2.7 \\
\hline & Capacity (t) & 11 & 5 & 11 \\
\hline Boom & Reach (m) & 7.2 & 5.7 & 10 \\
\hline
\end{tabular}




\subsection{Cost Structure}

Since 2006, unified cost records were kept for individual machines in the company bookkeeping. No major methodical changes of accounting were introduced since. Comprehensive accounting data on costs were aggregated into four cost groups [35]: (i) amortization; (ii) services; (iii) material; and (iv) personnel costs. Costs such as taxes, financial costs, transfer costs, etc. either did not apply or were not directly connected with the operation of individual machines and were therefore not considered. Records were converted from Czech Crowns into EURO by the mean annual EUR/CZK exchange rate.

\subsection{Machine Utilization}

Besides the costs, temporal (operational time, delays) and production (forwarded timber volume) parameters of the machines were observed. Temporal utilization of the machines was calculated as the share of operational hours on the scheduled annual working time. The formula was as follows (1):

$$
T U=\frac{O T}{O T+D T} \times 100
$$

where:

TU-temporal utilization (machine hours; $\mathrm{MH}$ )

OT-operational time of the machines (MH).

$D T$-delays, i.e., time, when the machines were not operational during working time due to repairs, maintenance or other reasons (scheduled machine hour; SMH).

Productivity of the machines was calculated as the number of produced $\mathrm{m}^{3} \mathrm{u}$.b. per $\mathrm{MH}$ (cubic meters of timber under bark per machine hours.

\subsection{Statistical Analyses}

Kolmogorov-Smirnov test was used to analyze the normality of distribution of the direct operational costs reached by the machines. Based on the outcomes of this analysis, a non-parametric Kruskal-Wallis test, was used to test the significance of differences between the total operational costs of timber forwarding per production unit (Euros per cubic meter of timber under bark; EUR $/ \mathrm{m}^{3}$ u.b.) reached by particular machines in individual years of their operation.

To enable a visual interpretation of the trends of the cost types of service costs, material costs, and personnel costs, their varying annual values were supplemented by linear trend estimates. The linear trends of particular cost types were constructed by fitting a line that resulted from using a least squares method on the data on the annual costs of a particular type per machine hour reached by the forwarders (i.e., EUR/MH).

\section{Results}

The gathered data were aggregated and processed into overview tables (Tables S1-S3). Overall, the mean annual utilization of the machines observed in this study ranged from 2080 to $2663 \mathrm{MH}$, based on the number of shifts and their duration (excluding delays). Utilization rates in particular years ranged between $63.8 \%$ and $89.3 \%$ for LVS (Table S1), $63.3 \%$ and $83.9 \%$ for JDA (Table S2), and between $64.4 \%$ and $74.3 \%$ for JDB (Table S3). Similar to the findings of other authors, operational costs decreased as the effective operational time increased.

The smallest LVS forwarder was deployed in stands with an MSV of $0.11 \mathrm{~m}^{3}$, forwarding timber over a mean distance of $389 \mathrm{~m}$. Mean annual volume of timber forwarded by the LVS was $14,059 \mathrm{~m}^{3}$ and the mean annual operational time was $2863 \mathrm{MH}$. Therefore, the machine achieved a mean productivity between 3.5 and $5.8 \mathrm{~m}^{3} / \mathrm{MH}$. Forwarder JDA was deployed in stands with a MSV of $0.29 \mathrm{~m}^{3}$. Mean forwarding distance was $321 \mathrm{~m}$ and mean annual productivity reached $24,725 \mathrm{~m}^{3}$, at a mean operational time of $2060 \mathrm{MH}$. Mean hourly productivity of this machine ranged from 7.4 to $10.3 \mathrm{~m}^{3} / \mathrm{MH}$. Forwarder JDB was deployed in stands with a MSV of $0.71 \mathrm{~m}^{3}$, forwarding timber over an average 
distance of $526 \mathrm{~m}$. Mean annual productivity was $24,321 \mathrm{~m}^{3}$ with the operational time of $2203 \mathrm{MH}$ on average. The hourly productivity of the JDB ranged from 10.3 to $12.3 \mathrm{~m}^{3} / \mathrm{MH}$. Cost analysis of the three forwarders proved that personnel costs were the most substantial direct operational costs of amortized forestry machinery (Table 3).

Table 3. Direct operational costs per machine hour (MH) of the forwarders.

\begin{tabular}{ccccccc}
\hline \multirow{2}{*}{ Item } & \multicolumn{3}{c}{$\begin{array}{c}\text { Forwarder Brand and Type } \\
\text { Novotný LVS } 5\end{array}$} & $\begin{array}{c}\text { John Deere 1010 } \\
\text { John Deere 1110E }\end{array}$ & \multicolumn{2}{c}{ John } \\
& (EUR/MH) & $\mathbf{( \% )}$ & (EUR/MH) & $\mathbf{( \% )}$ & (EUR/MH) & $\mathbf{( \% )}$ \\
\hline Amortization & 3.0 & 11 & 6.4 & 16 & 31.5 & 42 \\
Services & 1.9 & 7 & 9.0 & 22 & 2.5 & 3 \\
Materials & 4.3 & 15 & 11.0 & 27 & 14.6 & 20 \\
Personnel & 19.2 & 67 & 14.2 & 35 & 26.1 & 35 \\
Total & 28.4 & 100.0 & 40.6 & 100.0 & 74.7 & 100.0 \\
\hline
\end{tabular}

Amortization expenses were calculated based on data available in Table 1 and Tables S1-S3. The purchase price, ranging from 84 to 331 thousand EUR. The share of amortization on the total direct operational costs over the life span of the forwarders ranged between $12.5 \%$ and $15.7 \%$. In those years, when the machines were not fully written-off, they amounted for approximately $42 \%$ of the annual direct operational costs of the machines. Due to the changes in the legal framework in Czechia, the amortization period differed for individual machines. John Deere 1010 was amortized over the course of eight years, until the year 2012, whereas LVS was amortized over the course of six years (until the year 2013), and was then sold for 14,800 EUR. The newest forwarder, JDB, is being amortized since February 2017. After amortizing the whole purchase price of the machine and related materials, no costs related to this group were recorded. Amortization amounted for 3.00 EUR/MH for LVS, 6.37 EUR/MH for JDA, and 31.54 EUR/MH for JDB. The effects of this cost group on the direct operational costs of a machine were apparent, as was the increasing trend of this cost group over time (mean annual increase was 1.18 EUR/MH), caused by the increasing purchase prices (Figure 2).

The share of service costs on direct operational costs ranged between $3.3 \%$ to $22.1 \%$, i.e., 1.87 to $8.98 \mathrm{EUR} / \mathrm{MH}$ (Figure 3). For LVS, service costs reached $7 \%$ of direct operational costs (1.87 EUR/MH), for JDA they reached $22.1 \%(8.98 \mathrm{EUR} / \mathrm{MH})$, and for JDB, they reached $3.3 \%$ (2.45 EUR/MH). 


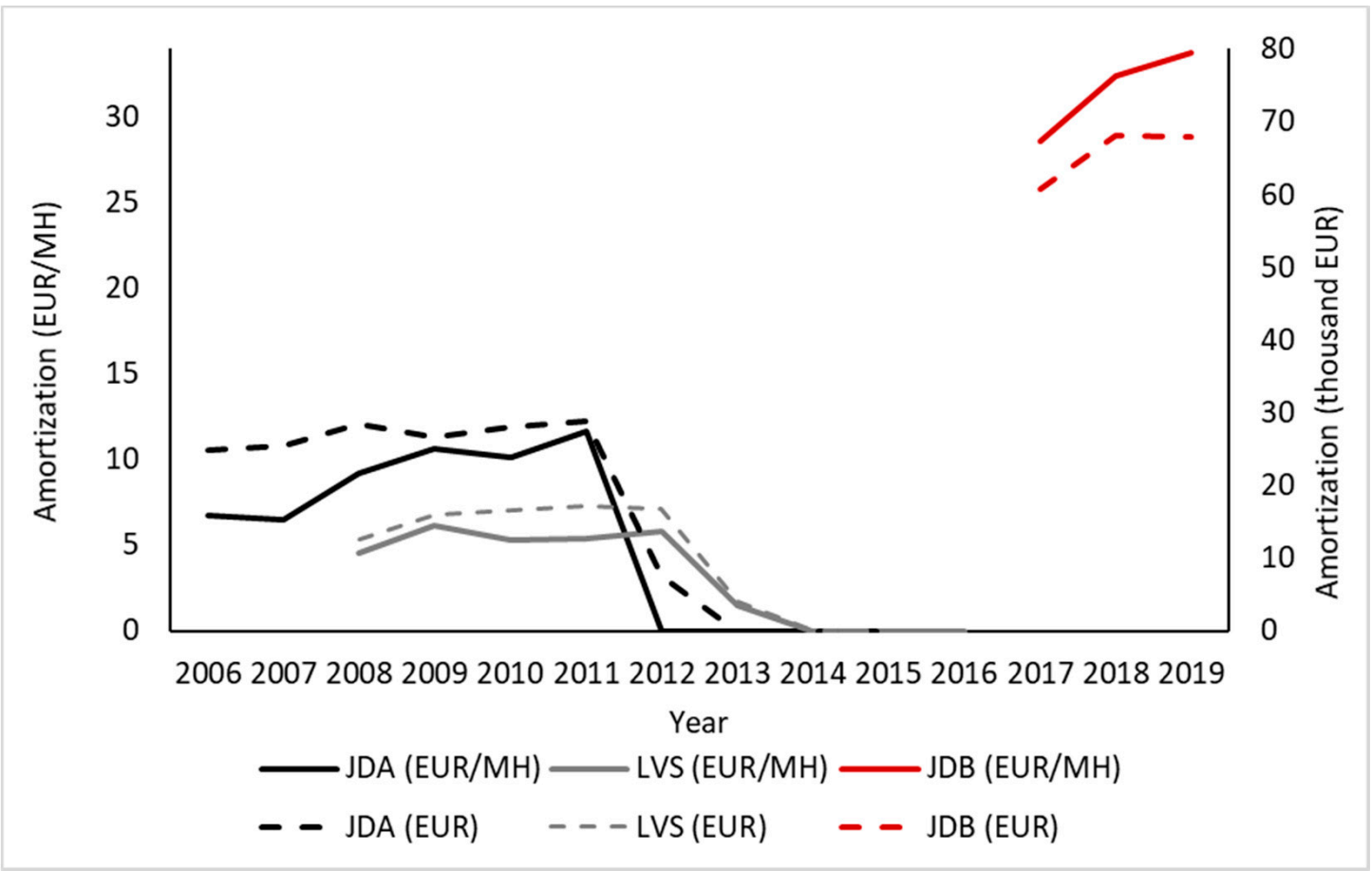

Figure 2. Amortization of the forwarders in the observed period. MH-machine hour; JDA-John Deere 1010; LVSNovotný LVS5; JDB-John Deere 1110E.

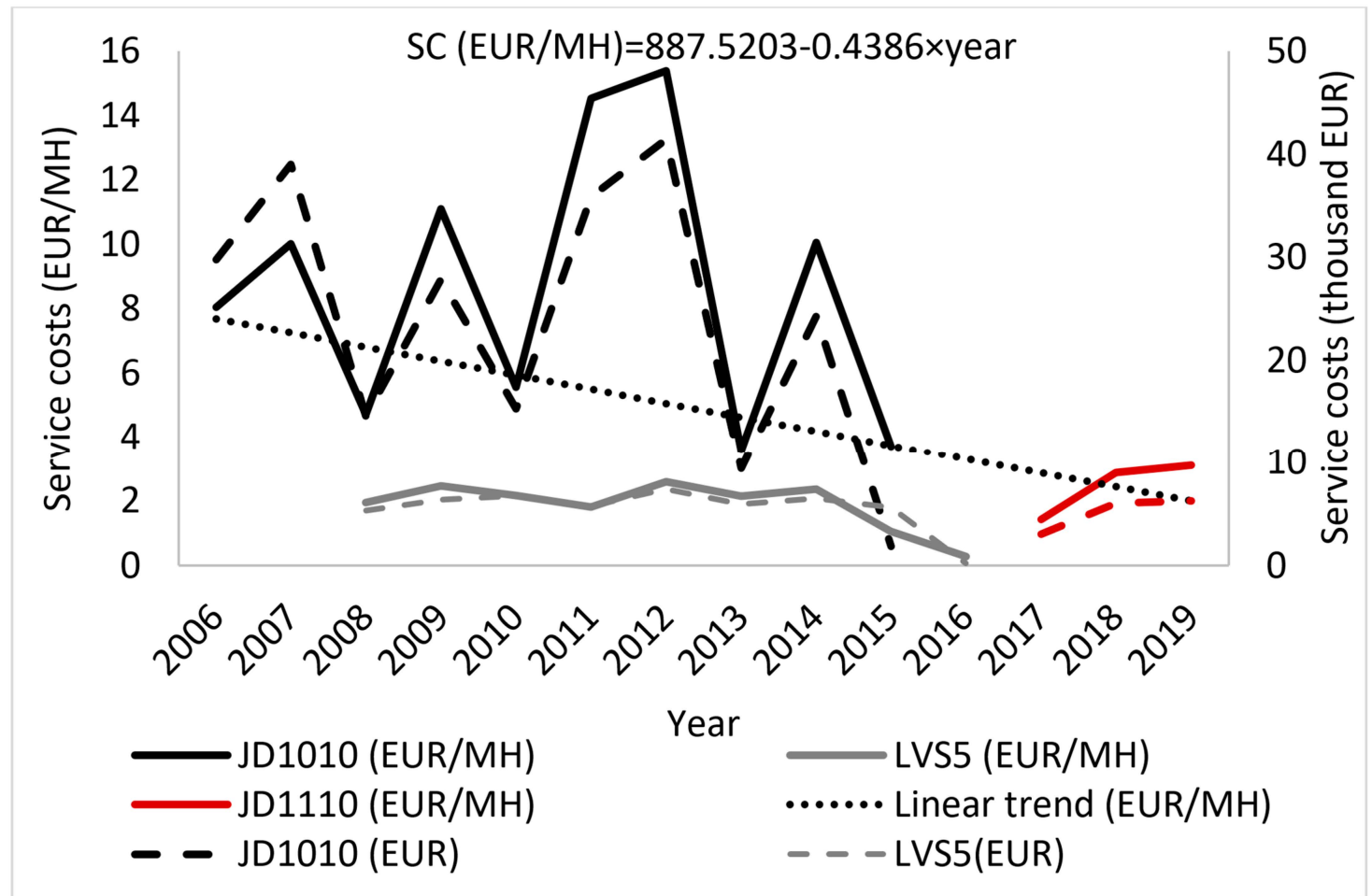

Figure 3. Service costs (repairs and maintenance) of the forwarders in the observed period. MH—machine hour JDA-John Deere 1010; LVS—Novotný LVS5; JDB—John Deere 1110E; SC—service costs.

The share of material costs on the direct operational costs was, on average, $14.9 \%$ (4.27 EUR/MH) for the LVS forwarder; 27.1\% (11.02 EUR/MH) for JDA, and 19.5\% (14.59 EUR/MH) for the JDB forwarder (Figure 4). The higher consumption of mate- 
rials by the John Deere machines was caused by their greater engine performance rating (Table 2), which translated into their higher productivity figures (Tables S2 and S3).

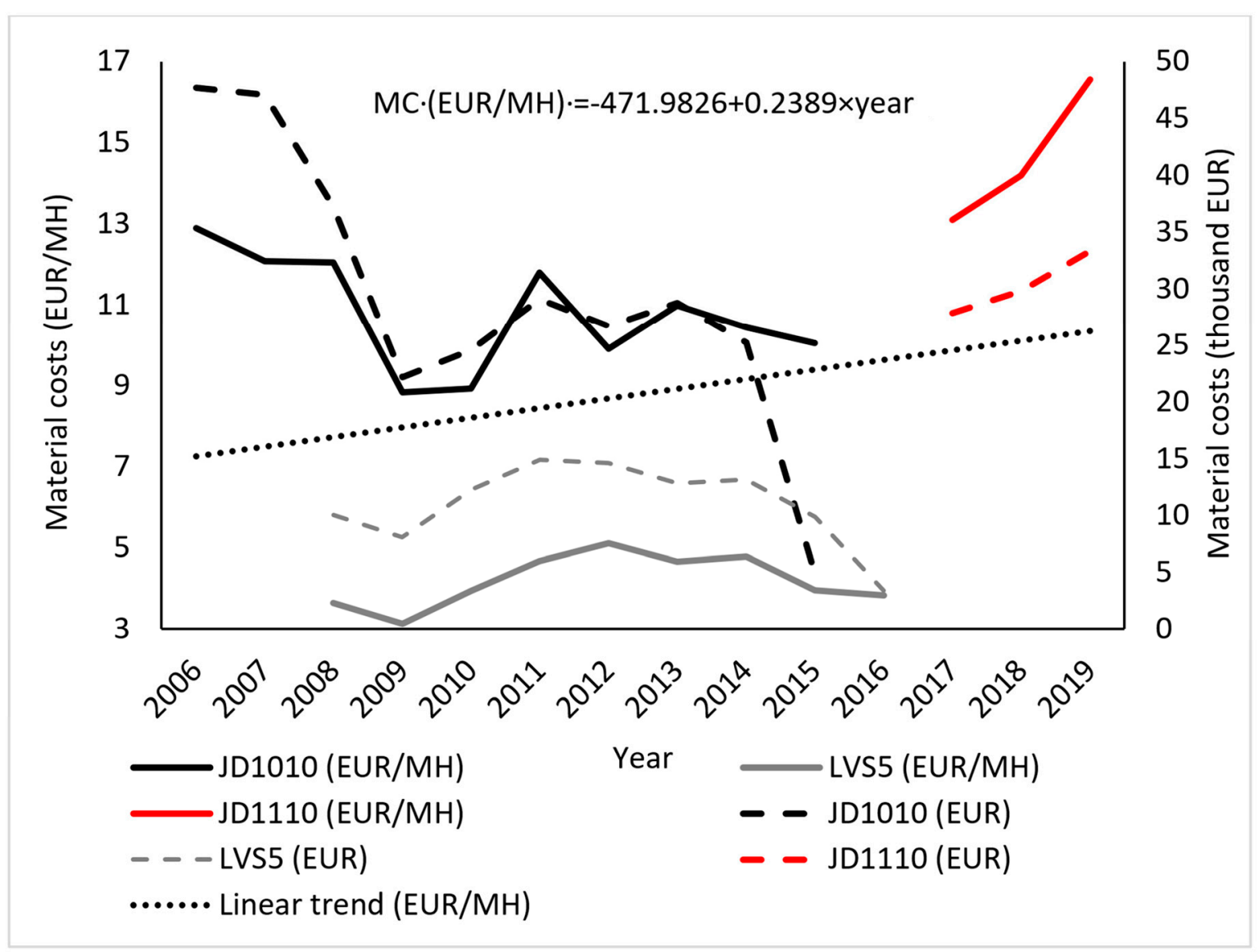

Figure 4. Costs of material (fuel, tires, spare parts) of the forwarders in the observed period. MH—machine hour JDA-John Deere 1010; LVS-Novotný LVS5; JDB-John Deere 1110E; MC—material costs.

The share of personnel costs on the direct operational costs of LVS was $65.6 \%$ (19.22 EUR/MH) on average, for JDA it was 35.1\% (14.26 EUR/MH), and for JDB, it was $35.0 \%$ (26.14 EUR/MH) (Figure 5). 


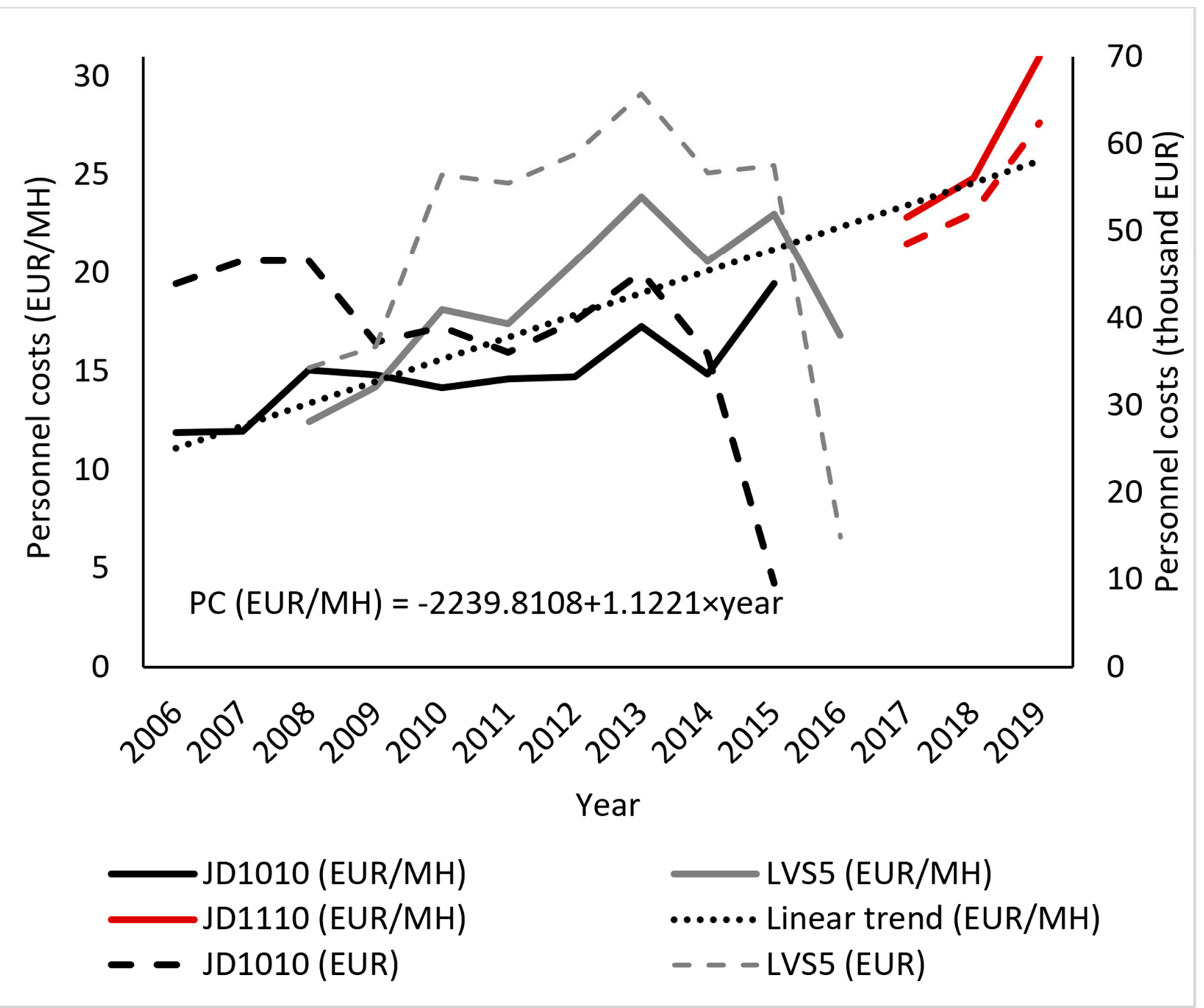

Figure 5. Personnel costs of the forwarders in the observed period. MH-machine hour JDA-John Deere 1010; LVSNovotný LVS5; JDB-John Deere 1110E; PC—-personnel costs.

The LVS forwarder, forwarded timber mostly from stands up to 40 years of age. The direct operational costs per cubic meter of forwarded timber ranged from 3.60 to $7.93 \mathrm{EUR} / \mathrm{m}^{3}$. John Deere 1010 reached costs ranging from 3.55 to $6.10 \mathrm{EUR} / \mathrm{m}^{3}$, whereas JDB reached costs from 6.22 to $7.22 \mathrm{EUR} / \mathrm{m}^{3}$.

The Kruskal-Wallis test, showed there were no significant differences between the three forwarders of two ends of the performance class $(p>0.05)$ (Figure 6). 


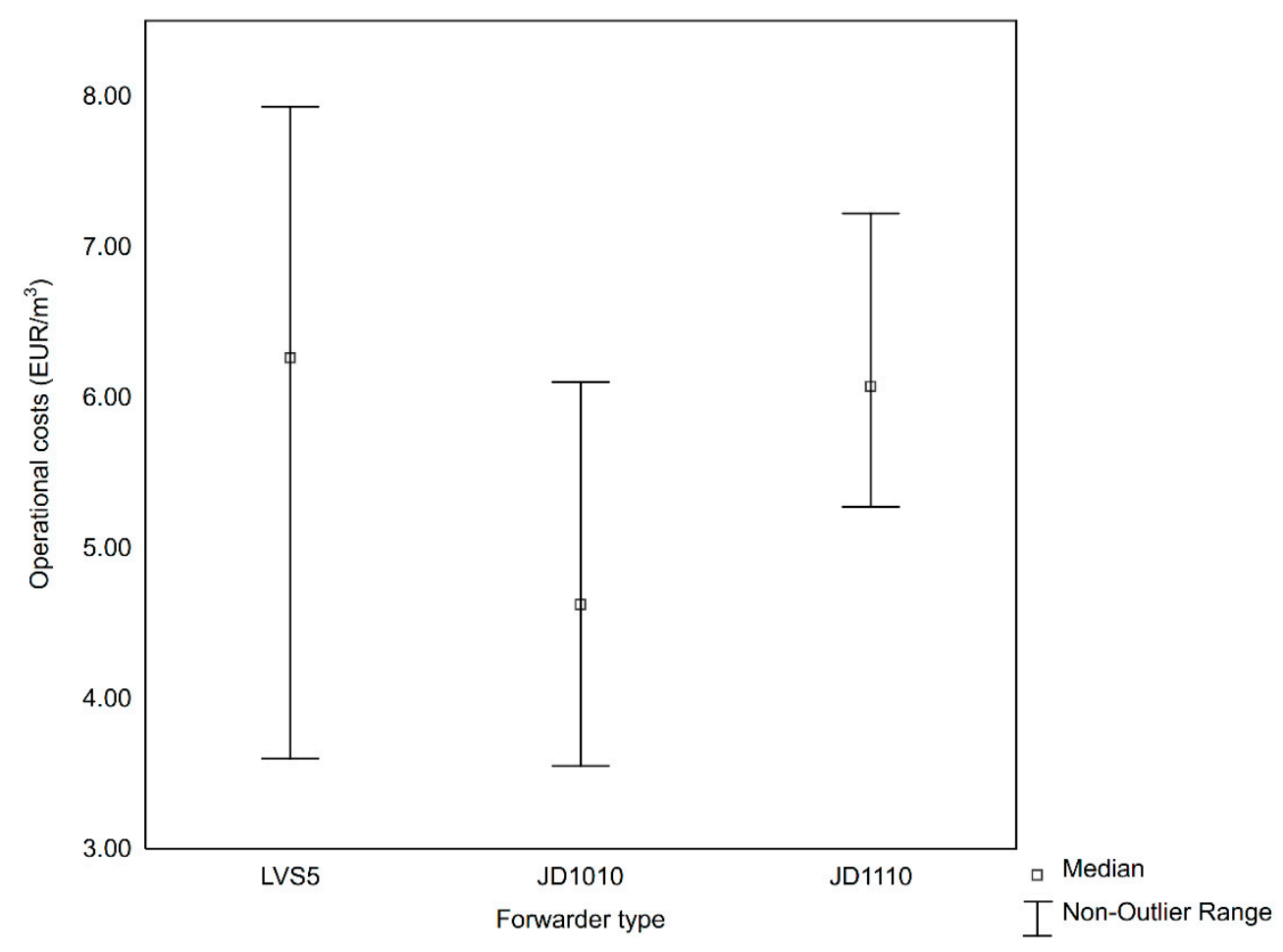

Figure 6. Results of the analysis of variance showing no statistically significant differences between the observed forwarder direct operational costs.

Besides the MSV, forwarding distance affects forwarding productivity per production unit (cubic meter) the most (Figure 7). Depending on the forwarding distance and MSV, direct operational costs per machine hour range from 4.34 to $6.29 \mathrm{EUR} / \mathrm{m}^{3}$.

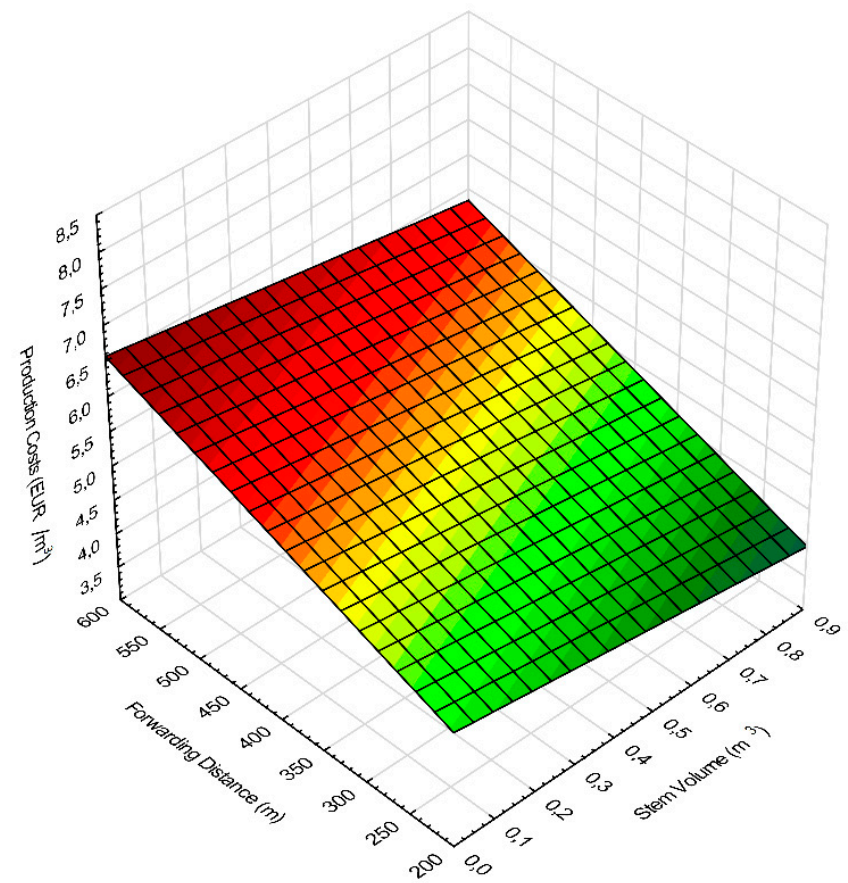

Figure 7. Relationship between direct operational costs of timber forwarding, mean volume of forwarded logs, and forwarding distance.

Direct operational costs of timber forwarding ranged from $3.55 \mathrm{EUR} / \mathrm{m}^{3}$ to $12.03 \mathrm{EUR} / \mathrm{m}^{3}$ based on the machine observed and the MSV. 
Vojenské lesy a statky operated their forwarders in tandem with a John Deere 770D (years 2008-2016) and a John Deere 1070 (years 2006-2014) harvester [36]. Based on the overlapping data from the harvesters and forwarders, we found that annual direct operational costs of the John Deere 770D and LVS tandem ranged from 150,000 to 278,000 EUR throughout the years 2008-2016, whereas the John Deere 1070D and JDA tandem reached annual direct operational costs in the range of 216,000 to 372,000 EUR throughout the years 2006-2014 (Figure 8).

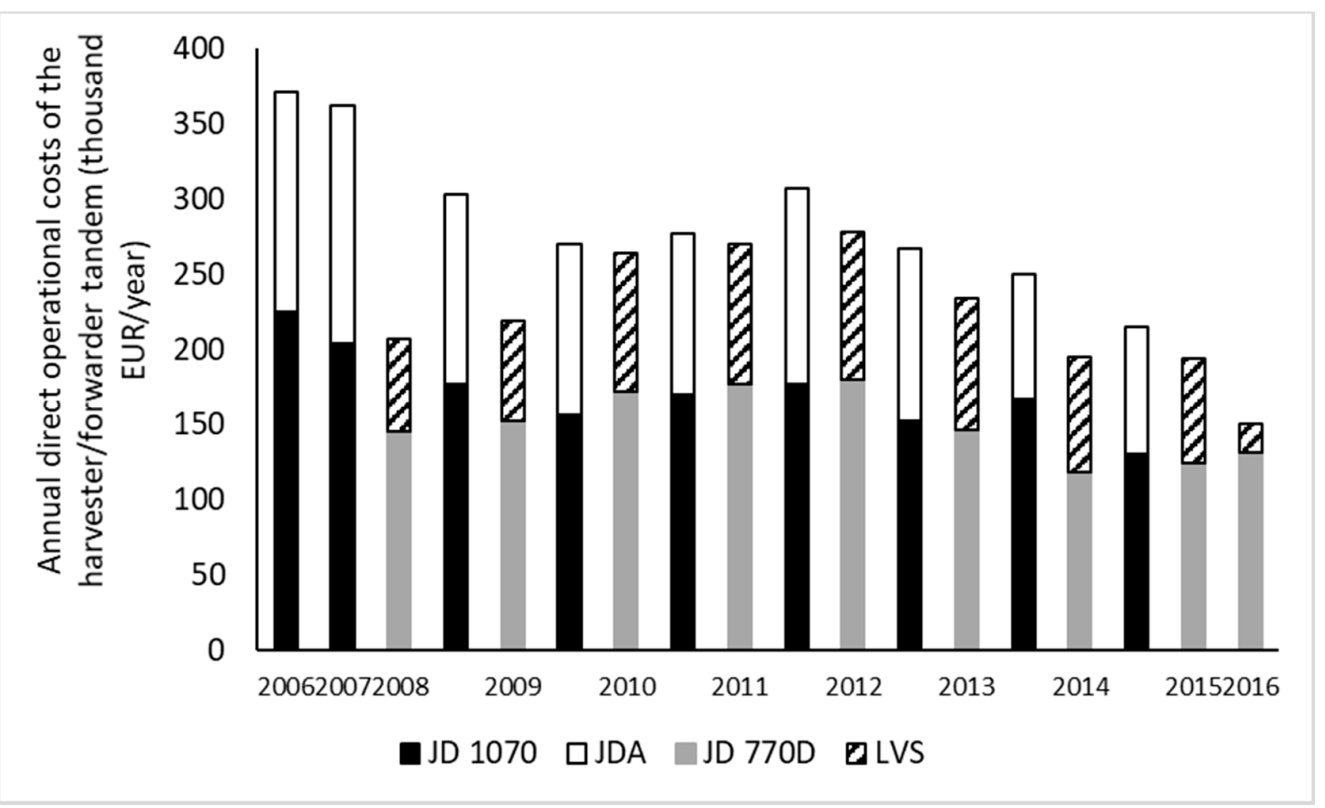

Figure 8. Annual direct operational costs of the harvester/forwarder tandems (supplemented from [37]). of the forwarders in the observed period. JD 1070-John Deere 1070 harvester; JDA-John Deere 1010 forwarder; JD 770D—John Deere 770D harvester; LVS—Novotný LVS5 forwarder.

\section{Discussion}

Confronting the results of this study with those from other authors was challenging. The costs were presented for particular countries, with all the differences in the underlying legal and economic frameworks, differing cost structures, reporting systems, production inputs, etc. The studies frequently observe technologies over a limited time, as opposed to observations throughout the whole amortization period. Most of them are case studies performed in a narrow interval of production conditions (e.g., single forest stand or a few), which make the results difficult to generalize. Several studies analyze the operational costs of harvesters or the whole harvester/forwarder tandem, but few separate the operational costs of timber forwarding $[37,38]$. However, analyzing the direct operational costs of timber forwarding separately is important, as forwarders do not have to work in tandem with harvesters [2].

The operational costs of timber forwarding ranged from 28.4 to 74.7 EUR/MH in the presented study. The forwarders were used in favorable settings, with suitable tree species compositions, sufficiently bearing soils, and mild slopes. These conditions play a substantial role in machine productivity, and subsequently in their operational costs, as the base over which the costs incurred are spread either scales up or down. Therefore, conditions that are connected to decreasing productivity, such as steep uphill slope, smaller MSV, salvage or incidental logging type, forwarding distance, limited operator experience, etc. cause an increase in forwarding costs $[7,10,15,19]$. Another factor were the differences in the structure of assortments produced. Transporting pulpwood can result in $43 \%$ higher costs compared to transporting sawlogs [26]. Unfortunately, we could not analyze this, as timber production varies greatly in short periods of time and records on the structure of assortments produced were impossible to link to cost data ex post. On the other hand, 
downhill slope, optimized use of machine payload, limiting the number of assortment types, introducing a midfield to the operations, and using experienced operators can increase forwarder productivity, thus improving their operational costs $[7,9,15,18]$.

Other than that, the aforementioned factors affect forwarding costs also in a more direct manner. With increasing uphill slope, forwarding distance, delays caused by operators or longer periods of time spent loading or unloading, the amount of consumed materials, such as fuel or tires, also increase. In the presented study, their share ranged between 4.3 and 14.6 EUR/MH, though in certain years, they increased by purchase of new tires (Figure 4). Besides fuel and tires, material costs included spare parts fitted or exchanged by the machine operators (such as chains, bars, and other parts of the power saw mechanism, etc.), replacement of more substantial machine parts were contracted to dedicated repair shops and were recorded as services. To compare, Austrian researchers reported that between the years 2004 and 2008, 18 forwarders with engine performance between 82 and $150 \mathrm{kw}$ reached mean material costs of $13 \mathrm{EUR} / \mathrm{PMH}_{15}$ [38].

Longer operational times also lead to excessive wear and tear or machine parts, which translate to increased service costs. However, perhaps the most important factors are the operators and their handling of the machine and work at hand [18,39]. If the machinery is well cared for and operated thoughtfully, service costs should theoretically increase only by the rate of inflation. This can be seen on Figure 3, when observing JDA. The high costs during the first two observed years can be attributed to the continuous operation in three shifts. The reckless approach of the operators in the first years caused several severe accidents (e.g., tearing a power line on the machine, which caused electrical damage to the machine and a need for a general repair of the engine). Figure 5 shows that using the three-shift operation with multiple operators, i.e., maximizing the utilization of the JDA forwarder, contributed to increased personnel costs during the first years of its operation. For these reasons, the company reduced the machine operation to a single 10 to 11 h-long shift per day, with a maximum of two operators in the rotation. Overall, personnel costs observed in this study were higher than, e.g., the $12 \mathrm{EUR} / \mathrm{MH}$ reported by Jiroušek et al. [28].

On the other hand, typical fixed costs, such as amortization, do not depend on machine utilization rates. In Czechia, a company is allowed to claim only a fixed amount of money per year as amortization. The amount depends on the amortization group (based on the typical lifespan of the machine that is being amortized) and the purchase price of the machine and its auxiliary systems. The purchase price of forest machines depends on the brand, capacity, boom type, and other equipment installed [28,40,41]. Therefore, maximizing utilization of forest machines will decrease their amortization costs per temporal or production unit, creating a possible competitive advantage for companies that can achieve the high utilization rates of their machines.

The machines observed were utilized to a standard degree, exceeding the $2000 \mathrm{~h}$ per year threshold of standard eight-hour shifts. To compare, other authors report mean annual temporal utilization of forwarders between 212 and 4,418 MH [34,40,42]. Rather than absolute utilization in $\mathrm{MH}$, utilization rates enable an easier comparison between several cases. In this study, machine utilization rates ranged between $63.3 \%$ and $89.3 \%$ of the scheduled time. Though these figures are lower than those of the machines observed by Proto et al. [10], forwarders typically reach about $75 \%$ to $80 \%$ rates [24,43]. Sufficient utilization of the machines plays a substantial role in their operational economy. Any company that operates forest machines therefore needs to optimize the size of their machines, so that the machines are able to work in suitable conditions. It is therefore vital to prepare forest stands for deployment of such machines in advance through proper planning of forwarding trail network and roadside landing location optimization, to minimize travel of the machines. Aside from planning the logging operations, a positive outcome of this study was the finding that there is no significant increase in operational costs when comparing machines from the opposite sides of their performance class. Thus, buying machines on the higher end of the performance class can be beneficial for companies that operate as 
contractors of logging operations, as will be able to deploy them in more diverse conditions. On the other hand, companies that own sufficient forest area have an even greater advantage, as they can scale the machine size to the operations they expect to be carrying out in the forests they own, thus achieving their high utilization rates.

\section{Conclusions}

Total operational costs increased annually for the LVS and JDB forwarders, a trend caused by the increase of personnel costs in case of the LVS and personnel and amortization for the JDB. Other costs types stagnated (materials consumption or services) for these machines. The JDA exhibited a decreasing trend, caused by the decreasing overall utilization of the machine and restriction of its operation from three shifts at the beginning of the observed period to one at its end. The differing trend of each machine pointed to the importance of optimizing the operational mode of forest machines to maximizing the efficiency of their use rather than maximizing their overall utilization. This conclusion was supported by the fact that the larger and more expensive machines did not significantly differ from the rather small LVS in terms of costs per production unit. We would like to point out that companies that operate their machines in forests they own have an advantage over machine operators who rely on being contractors of harvesting operations. The latter must consider the wider set of conditions, for which their machines are to be used, whereas the former can scale the machines they intend to purchase and the parameters of those machines exactly to the conditions found in their forests, thus decreasing the potential for inefficiencies or underutilization of their machines.

In terms of costs types, the companies that operate forwarders should pay attention to their personnel, as this was the only cost type that exhibited a steady increase for all observed machines. The trend was likely driven by the developments on the labor market, increasing share of CTL operations on total harvested volume in Czechia and the subsequent increasing competition for skilled operators by companies operating CTL machines. The second largest cost group was amortization, in the years when the machines were amortized. This points to the high capital intensity of fully mechanized logging, which should be compensated by high productivity and lower sum of operational costs per production unit over the lifespan of the machinery purchased, to make the purchase a sound business decision.

The costs of forest operations will trickle down to the price of bio-based products, affecting their ability to compete with their traditional, fossil-based counterparts. Therefore, increasing the efficiency of forest operations and all other parts of forest value chains is a key element of increasing the scale and scope of the global bioeconomy, an economic concept expected to play a substantial role in mitigating the effects of climate change. If we want to simultaneously keep or improve the ergonomics and quality of work environment, for which there is a considerable social demand, we need to achieve minimal costs of production per production unit through sophisticated machines, such as forwarders and gradually decrease the direct exposure of workers to the forest exterior.

Supplementary Materials: The following are available online at https:/ / www.mdpi.com/article/10 .3390 /f12040435/s1, Table S1: Timber production and direct operational costs of the Novotný LVS5 forwarder, Table S2: Timber production and direct operational costs of the John Deere 1010 forwarder, Table S3: Timber production and direct operational costs of the John Deere 1110E forwarder.

Author Contributions: Conceptualization, J.D., M.C. and P.N.; methodology, J.D., M.J. and M.C.; investigation, J.D., M.J., O.N., P.N., M.K. and R.L.; resources, J.D. and M.C.; data curation, M.J., P.N., R.L. and M.K.; writing —original draft preparation, J.D., M.J., M.C., O.N. and M.K.; writing-review and editing, P.N., O.N., R.L. and M.K.; visualization, M.J., P.N., O.N., R.L. and M.K.; supervision, J.D.; project administration, J.D.; funding acquisition, J.D. All authors have read and agreed to the published version of the manuscript. 
Funding: This study was supported by the Ministries of Education Youth and Sports from Poland and Czech Republic under the projects PPN/BCZ/2019/1/00013 (Poland) and 8J20PL062 (Czech Republic) "Analysis of the Impact of Harvester Technology on Forest Ecosystem depending on Work Performance", run by University of Agriculture in Krakow and Czech University of Life Sciences Prague and National agency for agriculture research; project No. QK1920391 “Analysis and Synthesis of Possibilities of Increasing the Potential of Bioeconomics in the Forestry and Wood Industry with a Focus on Innovation Systems and Technological Development", researched by members of the Faculty of Forestry and Wood Sciences of the Czech University of Life Sciences Prague.

Institutional Review Board Statement: Not applicable.

Informed Consent Statement: Not applicable.

Data Availability Statement: 3rd Party Data.

Conflicts of Interest: The authors declare no conflict of interest.

\section{References}

1. Dvořák, J.; Bystrický, R.; Hrib, M.; Hošková, P.; Jarkovská, M.; Kováč, J.; Krilek, J.; Natov, P.; Natovová, L. The Use of Harvester Technology in Production Forests, 1st ed.; Lesnická Práce: Kostelec nad Černými Lesy, Czech Republic, 2011; p. 156.

2. Ministry of Agriculture of Czech Republic. Zpráva o Stavu Lesa a Lesního Hospodárství České Republiky v Roce 2019 [Report on the State of Forests and Forestry in the Czech. Republic in the Year 2019]; Ministr of Agriculture of the Czech Republic: Prague, Czech Republic, 2020; p. 124.

3. Moskalik, T.; Borz, S.A.; Dvořák, J.; Ferenčík, M.; Glushkov, S.; Muiste, P.; Lazdinš, A.; Styranivsky, O. Timber harvesting methods in eastern european countries: A review. Croat. J. For. Eng. 2017, 38, 231-241.

4. Dvořák, J.; Natov, P.; Bystrický, R. Plošný a výrobní potenciál pro harvestorovou technologii v ČR [Spatial production potential of harvester technology in the Czech Republic]. Lesn. Práce 2018, 97, 54-57.

5. Dvořák, J.; Natov, P. Plošný Výrobní Potenciál Pro Harvestorovou Technologii v ČR k 31. 12. 2015 (Specializované Mapy s Odborným Obsahem) [Spatial Production Potential of Harvester Technology in the Czech. Republic on the Date of December 31, 2015 (Specialized Maps)]; Czech University of Life Sciences Prague: Prague, Czech Republic, 2016; p. 32.

6. Shrestha, S.P.; Lanford, B.L.; Rummer, R.B.; Dubois, M. Utilization and Cost of Log Production from Animal Logging Operations. Int. J. For. Eng. 2005, 16, 167-180. [CrossRef]

7. Cadei, A.; Mologni, O.; Röser, D.; Cavalli, R.; Grigolato, S. Forwarder productivity in salvage logging operations in difficult terrain. Forests 2020, 11, 341. [CrossRef]

8. Routa, J.; Nuutinen, Y.; Asikainen, A. Productivity in mechanizing early tending in spruce seedling stands. Croat. J. For. Eng. 2020, 41, 1-11. [CrossRef]

9. Mederski, P.S.; Venanzi, R.; Bembenek, M.; Karaszewski, Z.; Rosińska, M.; Pilarek, Z.; Luchenti, I.; Surus, M. Designing thinning operations in 2nd age class pine stands-economic and environmental implications. Forests 2018, 9, 335. [CrossRef]

10. Proto, A.R.; Macrì, G.; Visser, R.; Harrill, H.; Russo, D.; Zimbalatti, G. Factors affecting forwarder productivity. Eur. J. For. Res. 2018, 137, 143-151. [CrossRef]

11. Santaniello, F.; Line, D.B.; Ranius, T.; Rudolphi, J.; Widenfalk, O.; Weslien, J. Effects of partial cutting on logging productivity, economic returns and dead wood in boreal pine forest. For. Ecol. Manag. 2016, 365, 152-158. [CrossRef]

12. Slamka, M.; Radocha, M. Results of harvesters and forwarders operations in Slovakian forests. Lesn. Časopis For. J. 2010, 56, 1-15. [CrossRef]

13. Javůrek, P.; Dvořák, J. Evaluation of total time consumption in harvester technology deployment in conditions of the forest sector of the Czech Republic. J. For. Sci. 2018, 64, 33-42.

14. Nurminen, T.; Korpunen, H.; Uusitalo, J. Applying the Activity-Based Costing to Cut-to-Length Timber Harvesting and trucking. Silva Fenn. 2009, 43, 847-870. [CrossRef]

15. Malinen, J.; Taskinen, J.; Tolppa, T. Productivity of cut-to-Length harvesting by operators ' age and experience. Croat. J. For. Eng. 2018, 39, 14-22.

16. Kärhä, K.; Poikela, A.; Palander, T. Productivity and costs of harwarder systems in industrial roundwood thinnings. Croat. J. For. Eng. 2018, 39, 23-33.

17. Zimelis, A.; Kaleja, S.; Luguza, S. Factors affecting productivity of machined logging in thinning using small size forest machines. Res. Rural Dev. 2018, 1, 47-52.

18. Manner, J.; Nordfjell, T.; Lindroos, O. Effects of the number of assortments and log concentration on time consumption for forwarding. Silva Fenn. 2013, 47. [CrossRef]

19. Berendt, F.; Tolosana, E.; Hoffmann, S.; Alonso, P.; Schweier, J. Harvester productivity in inclined terrain with extended machine operating trail intervals: A german case study comparison of standing and bunched trees. Sustainability 2020, 12, 9168. [CrossRef]

20. Natov, P.; Dvořák, J.; Jankovský, M. Guidelines for Scaling Timber by Harvesters in the Czech. Republic 2018, 1st ed.; Natov, P., Dvořák, J., Jankovský, M., Eds.; Czech University of Life Sciences in Prague: Prague, Czech Republic, 2020; p. 96.

21. Schlagmerský, A. Zeitstudien [Time Studies], 1st ed.; Fachhochschule Hildesheim: Hildesheim, Germany, $1994 ;$ p. 122. 
22. Mederski, P.S.; Bembenek, M.; Karaszewski, Z.; Łacka, A.; Szczepańska-álvarez, A.; Rosińska, M. Estimating and modelling harvester productivity in pine stands of different ages, densities and thinning intensities. Croat. J. For. Eng. 2016, 37, 27-36.

23. Nouzová, J. Výkonové Normy v Lesním Hospodářství [Production Standards in Forestry], 1st ed.; Akcent s.r.o.: Vimperk, Czech Republic, 1988; p. 137.

24. Eriksson, M.; Lindroos, O. Productivity of harvesters and forwarders in CTL operations in northern Sweden based on large follow-up datasets. Int. J. For. Eng. 2014, 25, 179-200. [CrossRef]

25. Hildt, E.; Leszczuk, A.; Donagh, P.M.; Schlichter, T. Time consumption analysis of forwarder activities in thinning. Croat. J. For. Eng. 2020, 41, 13-24. [CrossRef]

26. Kellogg, L.D.; Bettinger, P. Thinning productivity and costs for a mechanized cut-to-length system in the Northwest Pacific coast region of the USA. J. For. Eng. 1994, 5, 43-54. [CrossRef]

27. Kärhä, K.; Rönkkö, E.; Gumse, S. Productivity and cutting costs of thinning harvesters of thinning harvesters. Int. J. For. Eng. 2004, 15, 43-56.

28. Jiroušek, R.; Klvač, R.; Skoupý, A. Productivity and costs of the mechanised cut-to-length wood harvesting system in clear-felling operations. J. For. Sci. 2007, 53, 476-482. [CrossRef]

29. Wöll, C.; Jónsson, L. Productivity and Cost Analysis of a Harvester Operation in Hallormsstadur, East. Iceland; Skograd ehf: Austurland, Iceland, 2009; p. 12.

30. Mizaras, S.; Sadauskienë, L.; Mizaraitë, D. Productivity of Harvesting Machines and Costs of Mechanized Wood Harvesting: Lithuanian Case Study. Balt. For. 2008, 14, 155-162.

31. Sirén, M.; Aaltio, H. Productivity and costs of thinning harvesters and harvester-forwarders. Int. J. For. Eng. 2003, 14, 39-48. [CrossRef]

32. Zimelis, A.; Kaleja, S.; Okmanis, M. Complex forest management system based on small size forest machines. Eng. Rural Dev. 2019, 18, 475-480.

33. Spinelli, R.; Magagnotti, N.; Picchi, G. Annual use, economic life and residual value of cut-to-length harvesting machines. J. For. Econ. 2011, 17, 378-387. [CrossRef]

34. Czechia. Act. No. 289/1995 Coll. On Forests (the "Forest Act"); Tiskárna Ministerstva vnitra p.o.: Prague, Czech Republic, 1995; p. 76.

35. Czechia. Regulation No. 500/2002 Coll. On Execution of the Act. No. 563/1991 Coll. On Accounting for Persons that Use Double Entry Accounting Systems; Tiskárna Ministerstva vnitra p.o.: Prague, Czech Republic, 2002; p. 174.

36. Dvořák, J.; Chytrý, M.; Natov, P.; Jankovský, M.; Beljan, K. Long-term cost analysis of mid-performance harvesters in Czech conditions [Langfristige Betriebskostenanalyse bei Harvestern mittlerer Leistung unter tschechischen Bedingungen]. Austrian J. For. Sci. 2019, 136, 351-372.

37. Di Fulvio, F.; Abbas, D.; Spinelli, R.; Acuna, M.; Ackerman, P.; Lindroos, O. Benchmarking technical and cost factors in forest felling and processing operations in different global regions during the period 2013-2014. Int. J. For. Eng. 2017, 28, 94-105. [CrossRef]

38. Holzleitner, F.; Stampfer, K.; Visser, R. Utilization Rates and Cost Factors in Timber Harvesting Based on Long-term Machine Data. Croat. J. For. Eng. 2011, 32, 501-508.

39. Purfürst, F.T. Learning Curves of Harvester Operators. Croat. J. For. Eng. 2010, 31, 89-97.

40. Spinelli, R.; Magagnotti, N. Performance and cost of a new mini-forwarder for use in thinning operations. J. For. Res. 2010, 15, 358-364. [CrossRef]

41. Carbone, F.; Picchio, R. Timber Buldings and Sustainability-Operative Machinery Costs Analysis within Forest Management Implementation Frame. In Timber Buildings and Sustainability; Concu, G., Ed.; Intech Open: London, UK, 2019 ; pp. $374-377$.

42. Holzleitner, F.; Kanzian, C.; Stampfer, K. Analyzing time and fuel consumption in road transport of round wood with an onboard fleet manager. Eur. J. For. Res. 2011, 130, 293-301. [CrossRef]

43. Spinelli, R.; Visser, R. Analyzing and Estimating Delays in Harvester Operations. Int. J. For. Eng. 2008, 19, 36-41. [CrossRef] 